\title{
A new species of Ocyale (Araneae, Lycosidae) from Madagascar, with first observations on the biology of a representative in the genus
}

\author{
Merlijn JOCQUE $^{1}$, Siel WELLENS ${ }^{2}$, J.D. ANDRIANARIVOSOA ${ }^{3}$, \\ F. RAKOTONDRAPARANY ${ }^{4}$, Sam THE SEING ${ }^{5} \&$ Rudy JOCQUÉ ${ }^{6, *}$
}

${ }^{1,2}$ Biodiversity Inventory for Conservation (BINCO), Walmersumstraat 44, 3380 Glabbeek, Belgium.

${ }^{1,2}$ Operation Wallacea, Wallacea House, Old Bolingbroke, Lincolnshire, PE23 4EX United Kingdom.

${ }^{1}$ Aquatic and Terrestrial Ecology (ATECO), Royal Belgian Institute of Natural Sciences (RBINS),

Vautierstraat 29, 1000 Brussels, Belgium.

${ }^{3,4}$ Mention Zoologie et Biologie Animale (MZBA), Université d'Antananarivo, Madagascar.

${ }^{5}$ Development and Biodiversity Conservation Action for Madagascar (DBCAM). Lot II A 93 L, Anjanahary, Antananarivo, Madagascar.

${ }^{6}$ Royal Museum for Central Africa, Leuvense Steenweg 13, 3080 Tervuren, Belgium.

${ }^{*}$ Corresponding author: rudy.jocque@africamuseum.be

${ }^{1}$ Email: merlijnjocque@gmail.com

${ }^{2}$ Email: siel.wellens@gmail.com

${ }^{3}$ Email: davsandrianarivosoa@gmail.com

${ }^{4}$ Email: felitenrecs@gmail.com

${ }^{5}$ Email: sam theseing@yahoo.fr

\footnotetext{
${ }^{1}$ urn:1sid:zoobank.org:author:6F4C1B5C-BDD9-4217-8F29-95ADA5E9F4D3

${ }^{2}$ urn:lsid:zoobank.org:author:B549CCD8-9A34-4FCD-996F-C49633331D33

${ }^{3}$ urn:lsid:zoobank.org:author:8F3B36C3-D80B-455D-B48E-50F27491167C

${ }^{4}$ urn:lsid:zoobank.org:author:487CF2F0-E5AC-4DF0-A2B2-4BCE6C7F8CB3

${ }^{5}$ urn:lsid:zoobank.org:author:28F7A019-1581-4C8B-B0CE-1C4948287F65

${ }^{6}$ urn:lsid:zoobank.org:author:CF15016C-8CD1-4C9D-9021-44CA7DC7A5D5
}

\begin{abstract}
A large white species of wolf spider, Ocyale ghost Jocque M. \& Jocqué R. sp. nov., is described from a white sandy beach of an inland freshwater lake in the northwest of Madagascar. The first photos of a living specimen of the genus Ocyale are provided together with some observations on the biology of the newly described species. An updated and illustrated key to the Afrotropical species of Ocyale is included here.
\end{abstract}

Keywords. Beach, biology, phenology, white sand.

Jocque M., Wellens S., Andrianarivosoa J.D., Rakotondraparany F., The Seing S. \& Jocqué R. 2017. A new species of Ocyale (Araneae, Lycosidae) from Madagascar, with first observations on the biology of a representative in the genus. European Journal of Taxonomy 355: 1-13. https://doi.org/10.5852/ejt.2017.355 


\section{Introduction}

A pilot study in northwestern Madagascar (Fig. 1), evaluating the added value of including spiders in an ongoing biodiversity monitoring program, revealed the presence of an undescribed species of Ocyale Audouin, 1823 (Lycosidae). Wolf spiders of this genus are among the larger representatives of the family but, despite their size, little is known about their habitat and biology.

The genus Ocyale contains 12 nominal species, but only the five Afrotropical representatives have been revised (Alderweireldt 1996). The genus is present in Asia (reported from China by Yin \& Peng 1997) but some of the descriptions from India-Ceylon leave doubt about the real identity of the specimens (Karsch 1879, 1892; Dyal 1935; Gajbe 2004). One species, O. pilosa Roewer, 1960, occurs both in Africa and Asia (Tikader \& Malhotra 1980; Alderweireldt 1996). The only Neotropical species, O. huachoi (Mello-Leitão, 1942), is most probably misplaced. This is the first substantiated record of the genus from Madagascar, wherein we describe a new species of Ocyale and present observations on its biology.

\section{Material and methods}

Spiders were collected at night in July-August 2016 during an expedition of Operation Wallacea in northwestern Madagascar (Fig. 1). All material is preserved in 70\% ethanol. Preserved specimens were observed and measured with a Leica M10 stereo microscope. Photographs were taken with a Leica MZ16 using Leica Application Suite; Leica Microsystems, 2011 automontage software. Specimens were

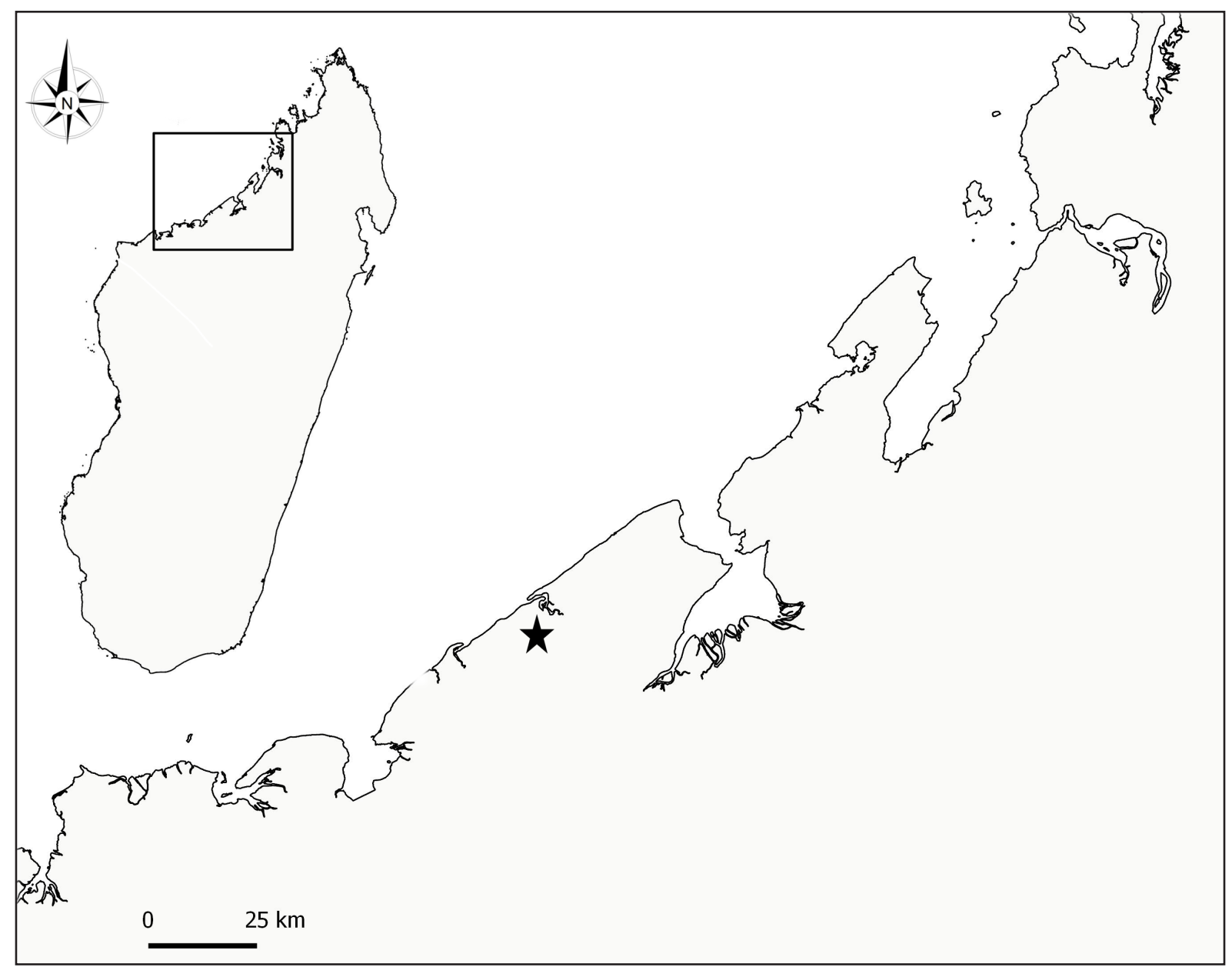

Fig. 1. Type locality of Ocyale ghost Jocque M. \& Jocqué R. sp. nov. 
immersed in K-Y brand jelly and then photographed to obtain a Z-stack of 15-25 images, which were subsequently merged into a single photomontage. A female epigyne was detached from the abdomen, digested using a tablet of Total Care Enzima product (protein removal system originally for cleaning contact lenses and containing Subtilisin A [0,4 mg/tablet]) and then immersed in $75 \%$ ethanol. For SEM photos, specimens were dried after immersion in absolute ethanol, gold coated then examined and photographed with a JEOL $6480 \mathrm{LV}$ scanning electron microscope. All material is deposited in the Royal Museum for Central Africa, Tervuren, Belgium (MRAC) and the Zoologie et Biodiversité Animale (ZBA) laboratory at the University of Antananarivo, Madagascar.

\section{Abbreviations}

All measurements are in $\mathrm{mm}$.

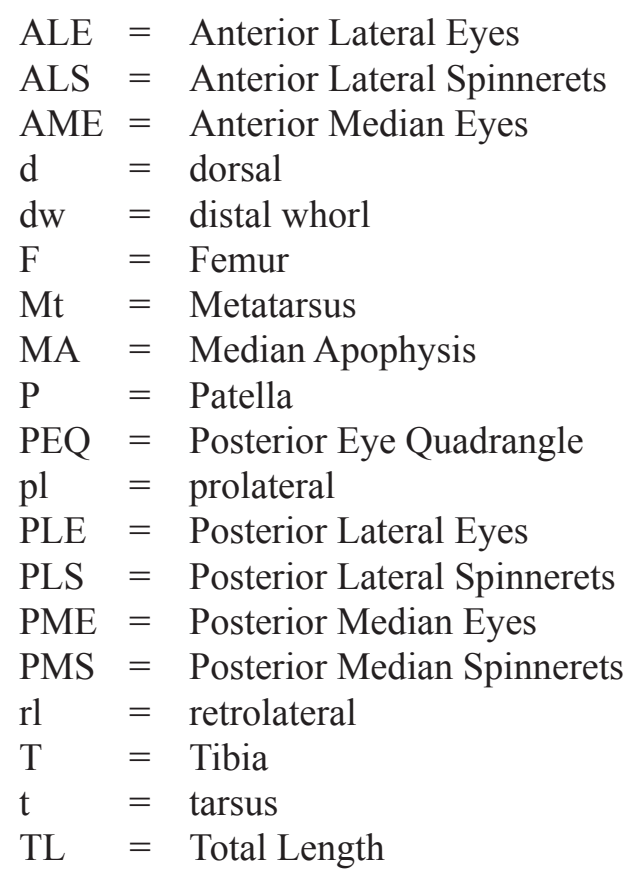

\section{Results}

Class Arachnida Cuvier, 1812

Order Araneae Clerck, 1757

Family Lycosidae Sundevall, 1833

Ocyale Audouin, 1823

\section{Key to the Afrotropical species of Ocyale}

Letters refer to characters shown by arrows in key figures.

Species included:

O. dewinterae Alderweireldt, 1996 $๋$ †

O. discrepans Roewer, 1960 ㅇ

O. ghost Jocque M. \& Jocqué R. sp. nov. $\widehat{0}$ 우

O. grandis Alderweireldt, 1996 숭

O. guttata Karsch, 1878 궁

O. pilosa Roewer, 1960 주우 


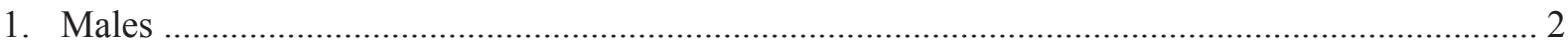

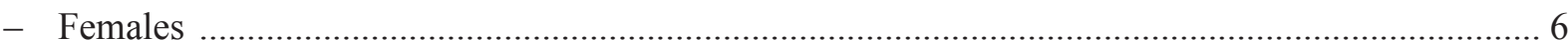

2. Small species: TL 6-8 mm; distal part of cymbium shorter than bulbus (b) and bulbus clearly broadened (a)

O. dewinterae Alderweireldt, 1996

- Larger species, TL $>16 \mathrm{~mm}$; distal part of cymbium longer than bulbus (c) and bulbus clearly not broadened (d)

3. Distal prong of palea much narrower than proximal prong (e); ventral process of MA subrectangular with long parallel margins (f)

O. ghost Jocque M. \& Jocqué R. sp. nov.

- Prongs of palea of similar size (g); long margin of ventral MA process with bulge (h) 4
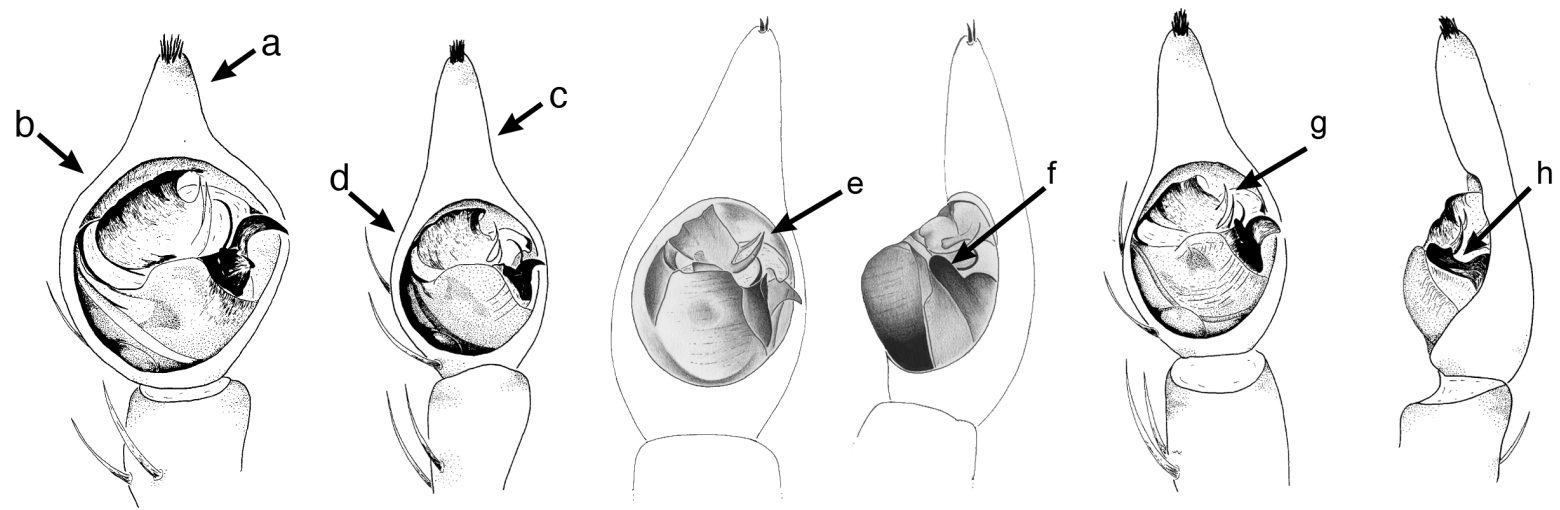

4. Lateral process of MA slender, tapered to sharp tip (i); TL $>23 \mathrm{~mm}$

O. grandis Alderweireldt, 1996

- Lateral process of MA, shorter and broader, blunt (j); TL $<23 \mathrm{~mm}$ 5

5. Sperm duct near proximal margin of tegulum, partly hidden by subtegulum (k); long margin of ventral MA process with deep long incision before bulge O. guttata Karsch, 1878

- Sperm duct further from proximal margin of tegulum, not hidden by subtegulum (1); long margin of ventral MA process with shallow, short incision before bulge $(\mathrm{m})$

O. pilosa Roewer, 1960

6. Epigyne surrounded but not covered by white setae (n) .... O. ghost Jocque M. \& Jocqué R. sp. nov.

- Epigyne almost completely covered by white setae (o) 7

7. Large species, $\mathrm{TL}>23 \mathrm{~mm}$; epigyne with small and short septum (p)

O. grandis Alderweireldt, 1996

- Smaller species, TL $<23 \mathrm{~mm}$; epigyne with well-developed inverted T-shaped septum (q, r) ........ 8
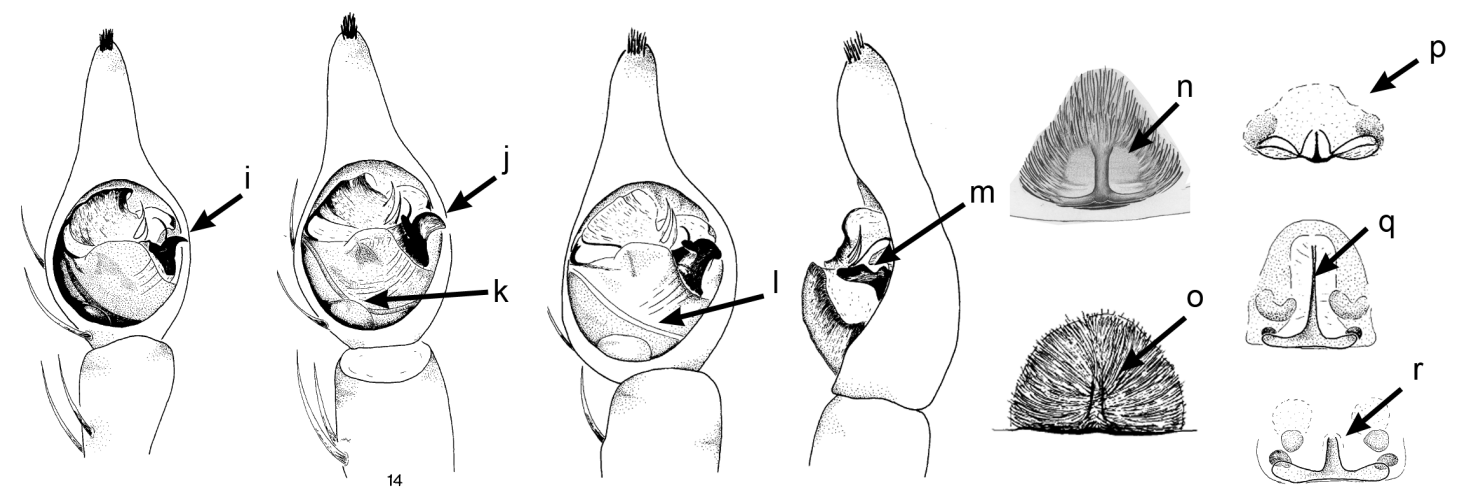
8. Longitudinal part of inverted $\mathrm{T}$ longer than transverse part (q); colour pattern uniform

O. dewinterae Alderweireldt, 1996

- Longitudinal part of inverted $\mathrm{T}$ as long as or shorter than transverse part (r); brown to yellow carapace pattern (in ethanol)

9. Lateral epigyne margins along median septum swollen and shiny; longitudinal part of inverted T slender, longer than transverse part

O. guttata Karsch, 1878, O. discrepans Roewer, 1960

- Lateral epigyne margins along median septum not swollen and shiny; longitudinal part of inverted T broad, only half as long as transverse part (r) O. pilosa Roewer, 1960

Ocyale ghost Jocque M. \& Jocqué R. sp. nov. urn:1sid:zoobank.org:act:37AAF237-A0C7-40D1-9BA8-6FF3D4864D79

Figs 1, 2, 3A-F, 4A-D, 5A-F, 6A-C, 7A-C

\section{Diagnosis}

Males of $O$. ghost sp. nov. can be recognized by details of the male palp: the tegulum is restricted to the prolateral side of the bulbus, the distal prong of the palea appendage is much narrower than the proximal one and the MA with the perpendicular prong is rectangular. Females are characterized by the epigyne in which the T-shaped posterior sclerite is fully exposed and not covered with setae as in other species in the genus.

\section{Etymology}

The species name 'ghost' refers to the fully white appearance of this spider. Additional reference is made to the large white direwolf 'Ghost' in Game of Thrones, the first book in the series of fantasy novels $A$ Song of Ice and Fire by George R.R. Martin.

\section{Type material}

\section{Holotype}

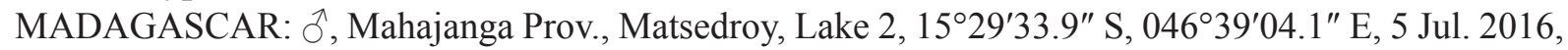
19:55-20:45, hand collected on sandy beach (Fig. 2), S. Wellens leg. (MRAC 245337).

\section{Paratypes}

MADAGASCAR: 1 q, 2 juvs, same data as holotype (MRAC 245338); 2 $q$,, 2 juvs, same data as preceding (MRAC 245340); 2 $q$, 2 juvs, as preceding (MRAC 245341); 2 + 9,2 juvs, as preceding

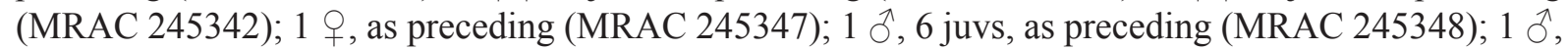
3 juvs, as preceding (MRAC 245361); 2 우, 2 juvs, as preceding (MRAC 245350); 1 q, 5 juvs, as preceding except 12 Jul. 2016 (MRAC 245339); 1 9, 5 juvs, as preceding except 22 Jul. 2016 (MRAC

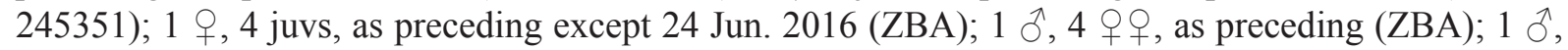
2 우, 1 juv., as preceding (ZBA).

\section{Description}

\section{Male (holotype)}

MEASUREMENTS. Total length 15.35; carapace 8.77 long, 2.27 high, 6.58 wide, narrowed to 3.95 in eye region; labium 1.14 wide, 0.79 long; sternum 3.68 long, 3.07 wide.

Colour. Alive (Fig. 3A-E): almost entirely white with slightly contrasting darker spots as in ethanol specimens; eyes surrounded by yellow rings; cheliceral condyle reddish brown. In ethanol (Fig. 4A-B): fairly different from colouration of live specimens; carapace brownish cream with interrupted black radiating striae, black fovea, two pairs of spots in front of fovea and dispersed irregular spots along 
margins; PEQ covered with white setae, tegument dark in its anterior half; chelicerae brown with dark setae as seen in frontal view, dark brown with black setae in ventral view; labium dark brown with cream crescent shape along anterior concave margin; sternum with strongly sinuous lateral margins, ending in long, tapered point; with dispersed short dark setae; legs formula IV-III-I-II; uniform cream with dispersed short, dark setae and dark spines; pedipalp: femur, patella and tibia cream, cymbium and bulbus contrasting dark brown; abdomen: dorsum cream with dispersed small dark spots, two reddish apodemes in anterior half and dispersed dark setae, sides and venter uniform cream; spinnerets: ALS dark, PLS and PMS pale on dorsal side, dark on ventral side.

Eyes. AME: 0.35; ALE: 0.15; PME: 0.67: PLE: 0.61; eye rows: ALE: 1.51, PME: 1.51, PLE: 2.18.

Chelicerae. With three teeth on retromargin, one small proximal tooth and one larger distal tooth on promargin.

Legs. Spination of leg I (identical on both sides): femur pl4, d3, rl2; patella pl1, rl1; tibia pl2, d2, rl2, v2-2-2; metatarsus p12, r12, v2-2, dw5. Leg measurements: see Table 1.

PALP (Figs 5A-D, 6A-C, 7A-B). Tegulum ribbed, developed on prolateral basal part of bulbus; palea with two prongs, proximal one broad and slightly curved, distal one thin and strongly curved; embolus originating on retrolateral part of palea and curved ventrally around it; MA large, with prolateral part a short hook, ventral part subrectangular, perpendicular to the former.

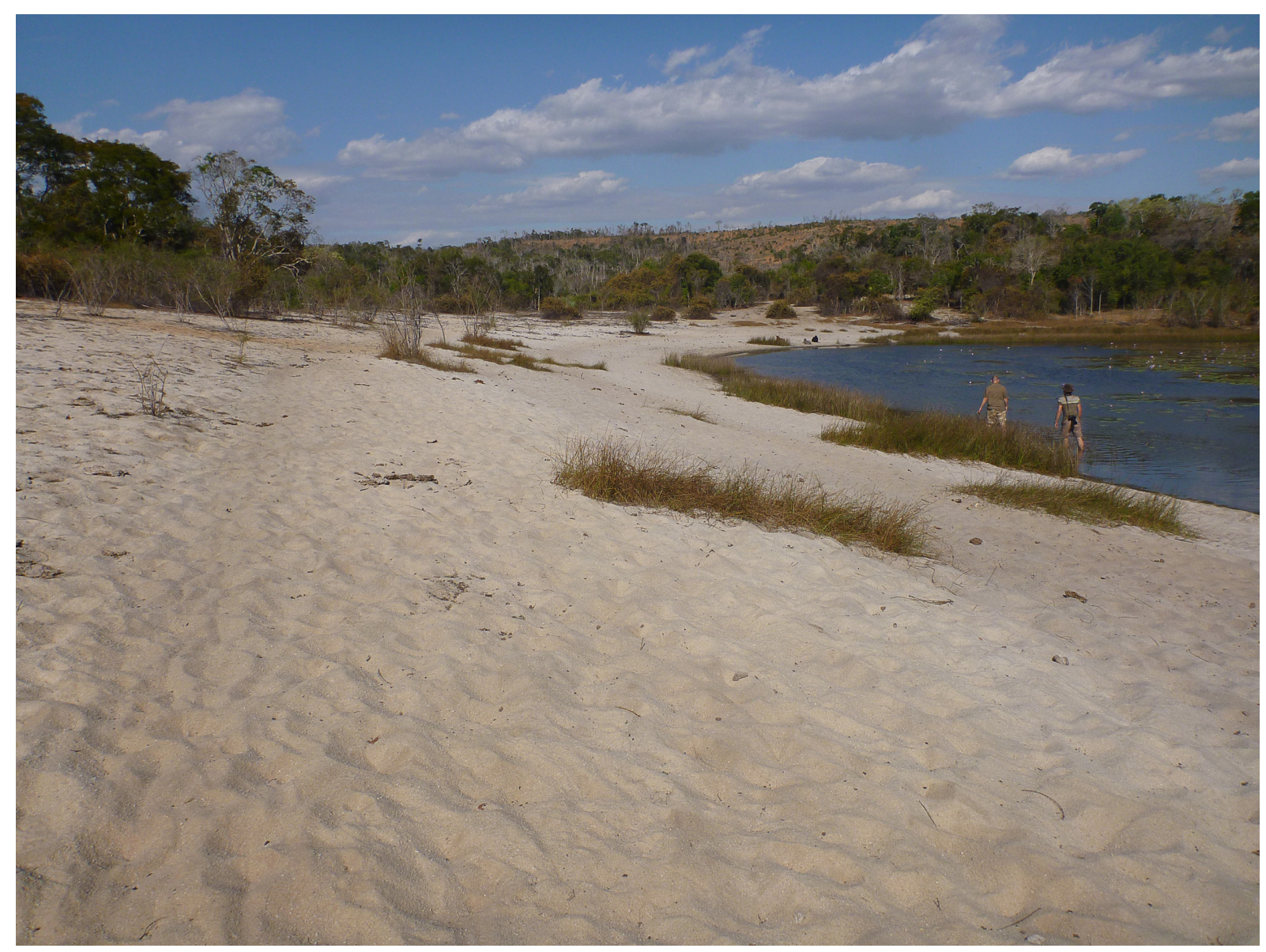

Fig. 2. Habitat on type locality of Ocyale ghost Jocque M. \& Jocqué R. sp. nov. (photo by MJ, July 2012). 

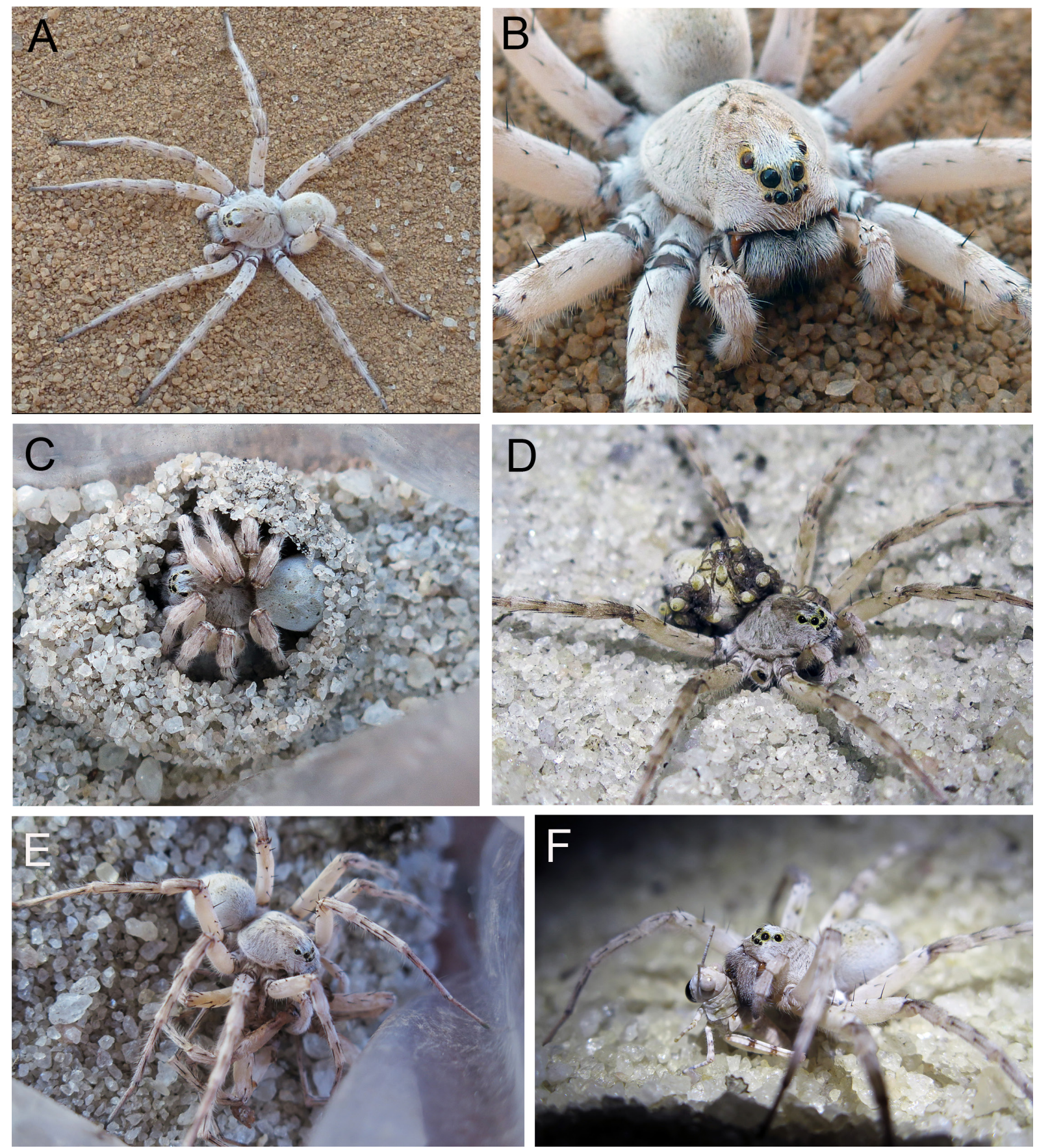

Fig. 3. Ocyale ghost Jocque M. \& Jocqué R. sp. nov. photographed at type locality. A. Female habitus. B. Same, detail. C. Female in sand retreat. D. Female with spiderlings on abdomen. E. Two males, one being eaten by the other. F. Female with white grasshopper prey. Photos A-B: MJ (2012), C-F: SW (2016). 

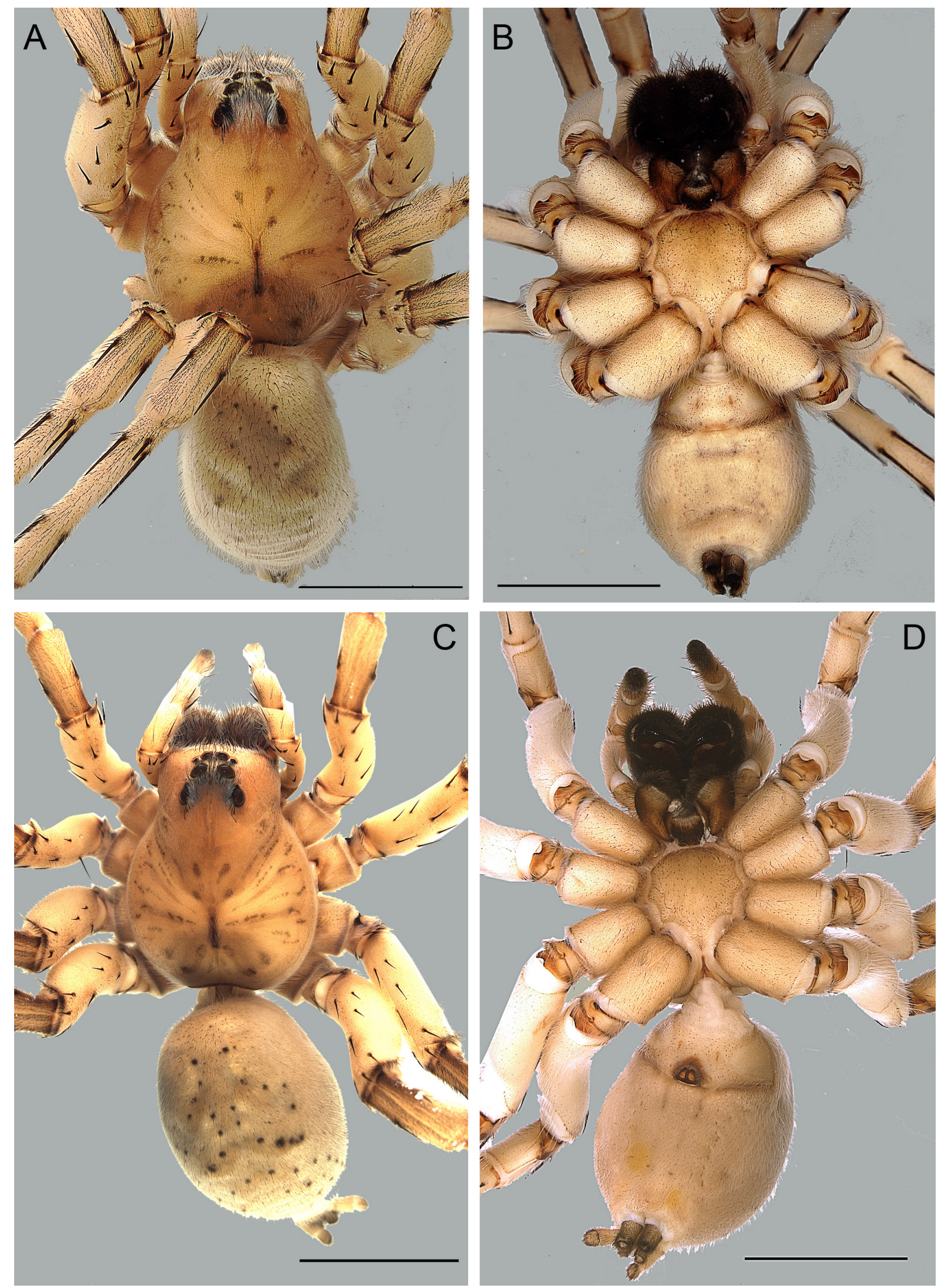

Fig. 4. Ocyale ghost Jocque M. \& Jocqué R. sp. nov. A-B. Holotype, ð. A. Dorsal habitus. B. Ventral habitus. C-D. Paratype, $q$ (MRAC 245338). C. Dorsal habitus. D. Ventral habitus. Scale bars $=0.5 \mathrm{~mm}$. 
Table 1. Leg measurements of male holotype and female paratype (MRAC 245338).

\begin{tabular}{lllllll}
\hline Male holotype (MRAC 245337) & Fe & P & Ti & Mt & t & Total \\
I & 6.82 & 3.83 & 6.25 & 5.68 & 4.83 & 27.41 \\
II & 6.82 & 3.41 & 5.96 & 6.39 & 4.54 & 27.12 \\
III & 7.24 & 3.12 & 5.96 & 7.67 & 4.97 & 28.97 \\
IV & 8.52 & 3.12 & 7.53 & 9.09 & 5.25 & 33.51 \\
Female paratype (MRAC 245338) & & & & & & \\
I & 7.24 & 4.12 & 5.40 & 5.82 & 3.98 & 26.55 \\
II & 6.67 & 3.41 & 4.97 & 5.40 & 3.69 & 24.14 \\
III & 7.81 & 3.83 & 5.40 & 6.53 & 4.69 & 28.26 \\
IV & 7.81 & 4.54 & 6.67 & 7.67 & 5.68 & 32.38 \\
\hline
\end{tabular}
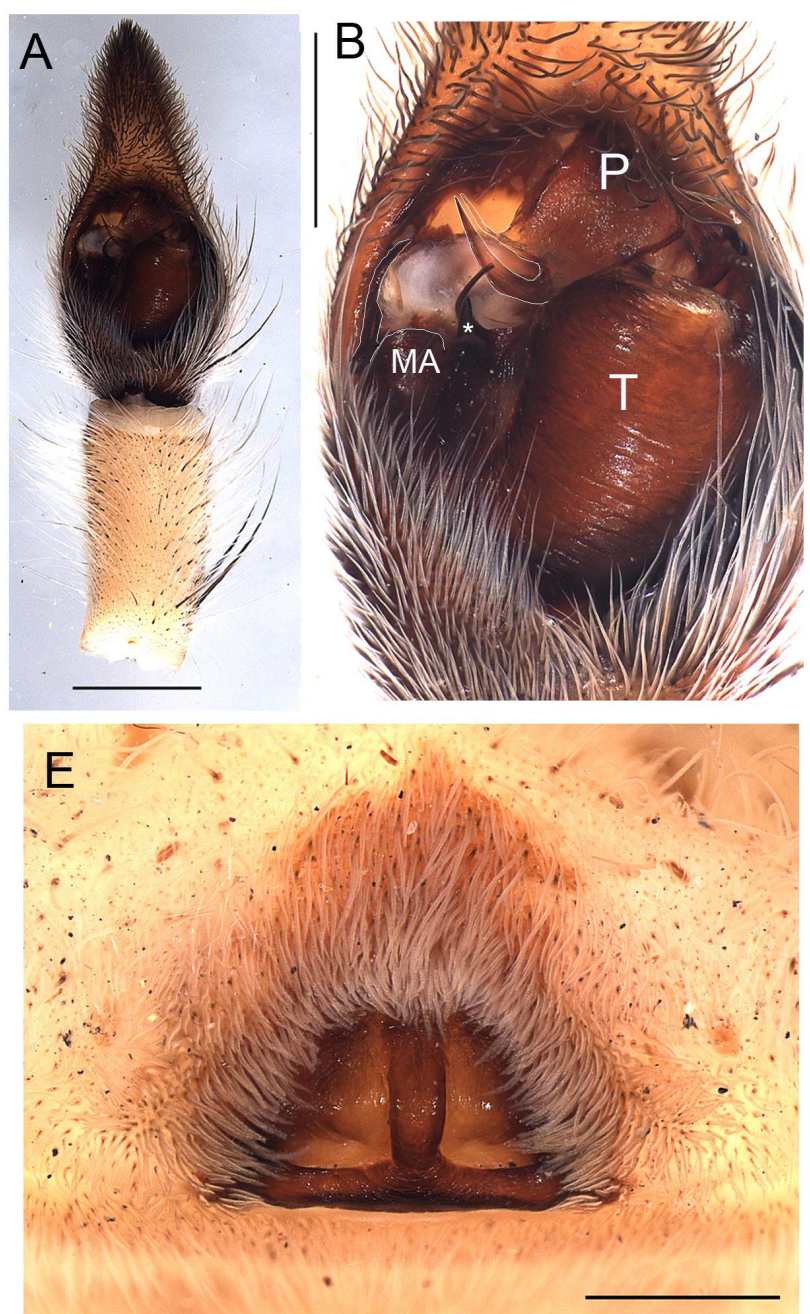
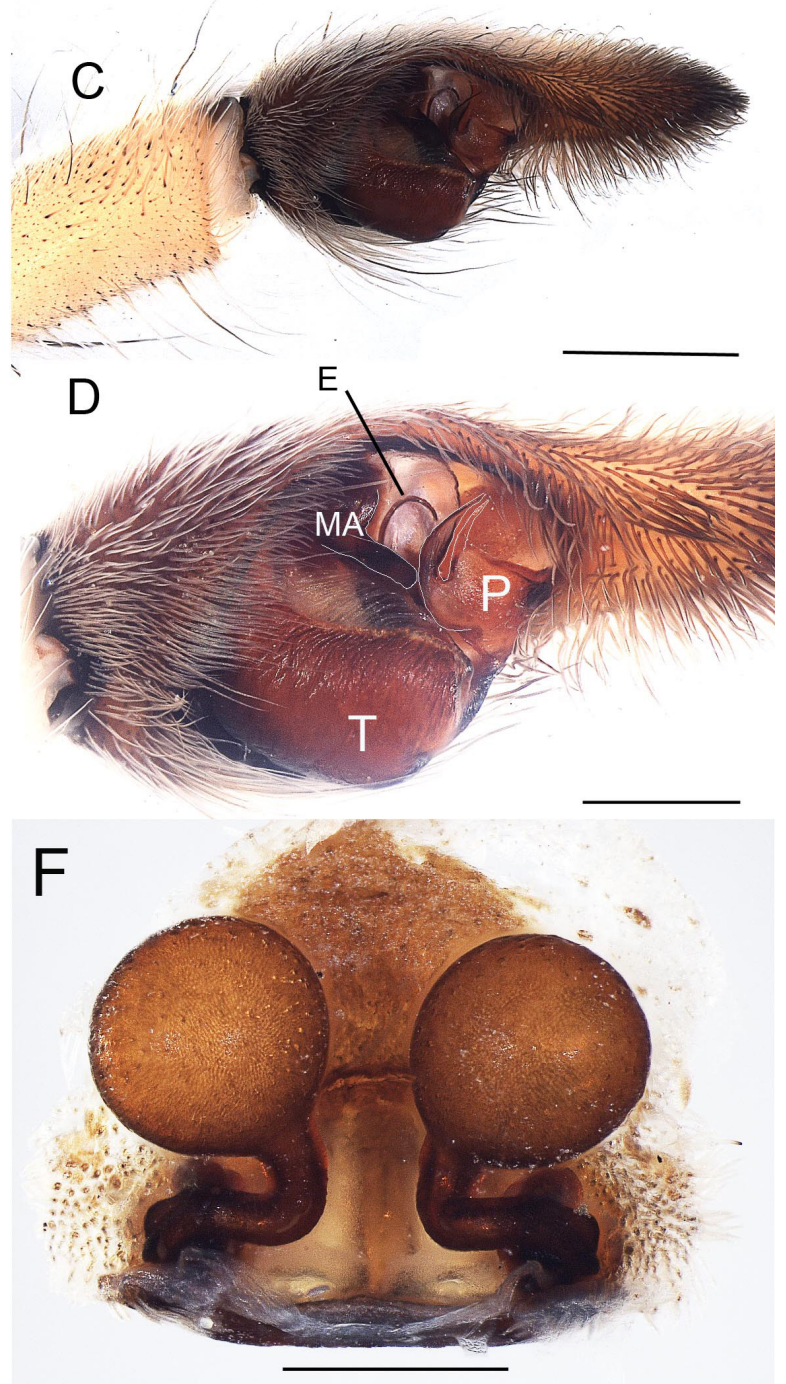

Fig. 5. Ocyale ghost Jocque M. \& Jocqué R. sp. nov. A-D. Palp, Ô, holotype. A. Ventral view. B. Same, detail. C. Lateral view. D. Same, detail. E-F. Epigyne, + , paratype (MRAC 245338). E. Ventral view. F. Digested, dorsal view. Abbreviations: $\mathrm{MA}=$ median apophysis; $\mathrm{P}=$ palea; $\mathrm{T}=$ tegulum; $\mathrm{E}, *=$ embolus. Scale bars $=0.5 \mathrm{~mm}$. 
Female (paratype MRAC 245338)

MEASUREMENTS. TL 16.24; carapace 7.95 long, 3.69 high, 6.31 wide, narrowed to 3.69 in eye region; labium 0.92 long, 1.08 wide; sternum 3.33 long, 2.83 wide.

Colour. In ethanol (Fig. 4C-D): dorsal surface of abdomen more uniform cream than in male but with similar dark spots and apodemes; pedipalp as in the male except for unmodified tarsus with dark tip.

Eyes. AME: 0.42; ALE: 0.21; PME: 0.67: PLE: 0.60; eye rows: ALE: 1.44, PME: 1.44, PLE: 2.14.

Legs. Spination of leg I, right (left): femur pl2(5), d3(4), rl3(3); patella pl1(1), rl1(1); tibia pl2(2), d1(1), rl2(2), v2-2-2 (3-2-2); metatarsus pl2(2), rl2(2), v2-2-2(2-2-2), dw5(5). Leg measurements: see Table 1.

EpIGYNe (Figs 5E-F, 7C). Roughly triangular area surrounded by dense mat of white setae; large and broad inverted T-shaped sclerite, 1.6 times wider than long; spermathecae large, globular; entrance ducts Z-shaped with basal portion slightly sinuous.

\section{Variation}

Males: TL 16.76-19.45 $(\mathrm{n}=5)$; females: TL 16.47-22.01 $(\mathrm{n}=19)$.
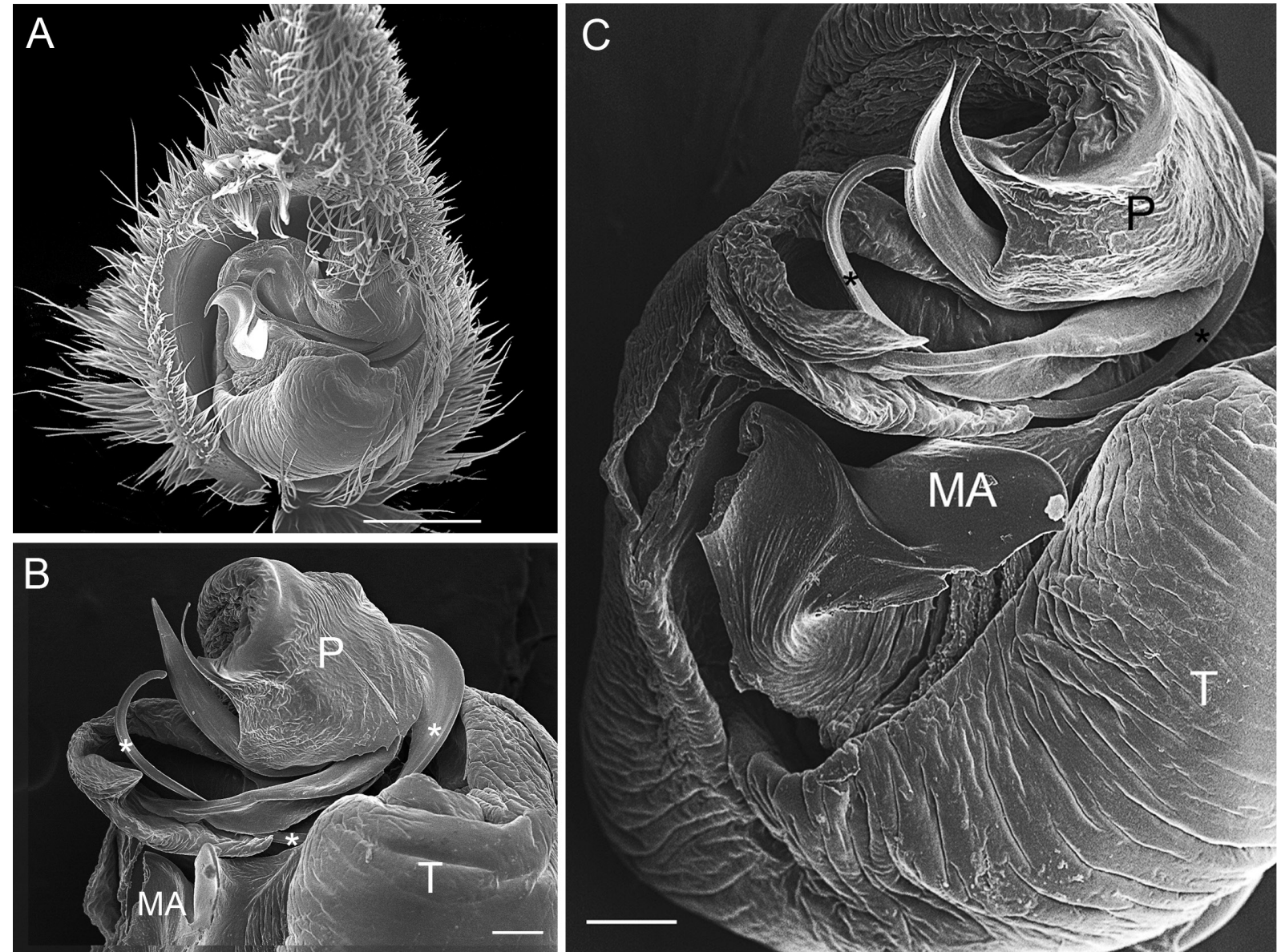

Fig. 6. Ocyale ghost Jocque M. \& Jocqué R. sp. nov., palp, Ô, paratype (MRAC 245361), scanning electron micrographs. A. Right palp, ventral view. B. Distal end of bulbus, ventral view. C. Main part of bulbus ventro-prolateral view. Abbreviations: $\mathrm{MA}=$ median apophysis; $\mathrm{P}=$ palea; $\mathrm{T}=$ tegulum; $*=$ embolus. Scale bars: $\mathrm{A}=0.5 \mathrm{~mm}$; $\mathrm{B}-\mathrm{C}=0.1 \mathrm{~mm}$. 


\section{Distribution}

Known only from the type locality (Fig. 1).

\section{Affinities}

We placed this species in the genus Ocyale based on the presence of the two elongate curved prongs on the palea (Figs 4B, 5B-C, 6B), the epigyne surrounded with white hairs and with a wide inverted T-shaped sclerite (Figs 5E, 7C), the large globular spermathecae (Fig. 5F) and the conformation of the copulatory ducts (Alderweireldt 1996: fig. 27). The specimen illustrated by Siyam et al. (2015: figs 13-15) from Sudan is probably not an Ocyale, at least not $O$. pilosa because the palp does not fit the illustrations of Alderweireldt (1996: figs 12-13). The colour pattern described for the genus in both these papers may be inaccurate based on the observed differences between specimens in ethanol and photos of the living spiders for this new species. This indicates the value of including images of living animals in descriptions of new species. It is not clear to which species the representative of Madagascar is most closely related to.

\section{Biology}

Ocyale ghost sp. nov. was only found on the white sandy beaches (Fig. 3A-B) of an inland lake in the study region. The surveys also included grassland and dry forest, but the species seems restricted to a

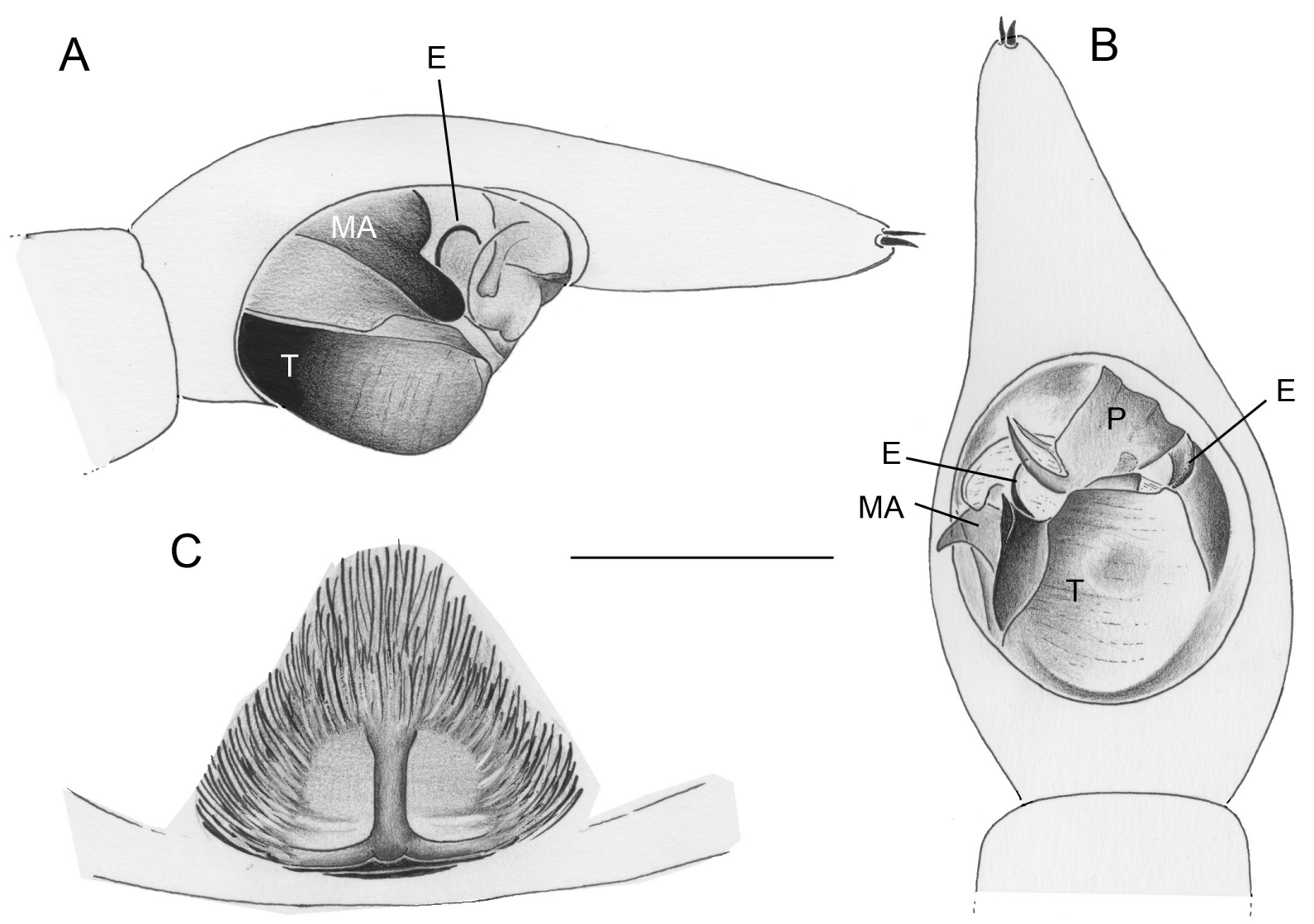

Fig. 7. Ocyale ghost Jocque M. \& Jocqué R. sp. nov. A-B. Palp (holotype, đ). A. Retrolateral view. B. Ventral view. C. Epigyne (paratype, + , MRAC 245338), ventral view. Scale bar $=1 \mathrm{~mm}$. Abbreviations: $\mathrm{MA}=$ median apophysis; $\mathrm{P}=$ palea; $\mathrm{T}=$ tegulum; $*=$ embolus . 
white-sand habitat, as reflected in its habitus. Ocyale ghost sp. nov. is active at night and all specimens were caught with headlamps after sunset. Captured animals that were kept alive in large ziplock bags overnight constructed retreats in the sand, lined with silk (Fig. 3C). Possible prey include large insects such as grasshoppers (Fig. 3F) that also exhibit camouflage colours as an adaptation to the white beach they live on. Intraspecific predation is also likely to occur (Fig. 3E), a phenomenon which is not unusual among lycosids (Edgar 1969; Hallander 1970). We observed copulation and females with spiderlings (Fig. 3D) in the midst of the dry season (June-July). Juveniles of a complete range of size, from very small ones $(6 \mathrm{~mm} \mathrm{TL})$ to subadults, were observed, indicating that this species might reproduce yearround. The permanent presence of water in its habitat might explain why this species is also active in the dry season when spider activity is on average very low.

\section{Discussion}

Species of Ocyale are among the larger and, as far as their colour is concerned, the most remarkable wolf spiders. Despite these features, virtually nothing is known about their biology. Our study is the first that provides photos of the animals in the field, showing striking differences between preserved and living specimens that stress the importance of documenting live patterns and colours in species descriptions. It is known that colours can fade when animals are fixed in ethanol, this phenomenon has been documented for other spiders. In Subasteron daviesi Baehr \& Jocqué, 2001, for instance, bright red and yellow abdominal spots become clear white in ethanol (Baehr \& Jocqué 2001). Another striking example is that of the male of Donacosa merlini Alderweireldt \& Jocqué, 1991, in which the striking pink hairs of the living male completely fade in alcohol (Alderweireldt \& Jocqué 1991). More remarkable is that in Ocyale ghost sp. nov., the chelicerae, which are white in live specimens, turn dark in preserved spiders.

The specimens of the type series of $O$. dewinterae Alderweireldt, 1996, were collected by RJ on white sandy beaches of Lake Malawi, showing a similar habitat occupancy as for Ocyale ghost sp. nov. Concerning ecology, the only other observations reported are from Dyal (1935) who described Ocyale kumari, a species from Pakistan, based on a single female specimen. The species was attributed to the genus Ocyale but the description does not provide many details and the illustration of the epigyne does not appear diagnostic for the genus. This species was found on a river bank in a fairly deep burrow $(4 \mathrm{~cm})$ and produces a sheet-web. Even these observations are not in accordance with the few records that relate the behaviour of Ocyale and rather point in the direction of Hippasa Simon, 1885.

In the survey on Madagascar, apart from Ocyale, only one other unidentified lycosid was found in very low numbers. The general paucity of wolf spiders encountered during field collections for this study reinforces the observation of Jocque et al. (2011) that Lycosidae are uncommon on Madagascar. This strongly contrasts with the situation on mainland Africa, where Lycosidae are among the most abundant spiders (Jocqué \& Alderweireldt 2006).

\section{Acknowledgements}

We would like to thank the people living around Mariarano for their collaboration and guidance on the numerous excursions in this region. Many thanks also to DBCAM for supporting the expedition of Operation Wallacea, and also to the enthusiastic volunteers who assisted with sample collection in the field. We are indebted to A. Reygel for the drawings of the palp and the epigyne and to T. Russell-Smith and M. Alderweireldt for useful comments on the first draft of this manuscript.

\section{References}

Alderweireldt M. 1996. A taxonomic revision of the genus Ocyale Audouin, 1826 in Africa (Araneae: Lycosidae). Journal of Natural History 30: 1349-1365. https://doi.org/10.1080/00222939600771261 
Alderweireldt M. \& Jocqué R. 1991. A remarkable new genus of wolf spiders from southwestern Spain (Araneae, Lycosidae). Bulletin van het Koninklijk Belgisch Instituut voor Natuurwetenschappen, Entomologie 61: 103-111.

Baehr B. \& Jocqué R. 2001. Revisions of genera in the Asteron-complex (Araneae: Zodariidae): new genera Pentasteron, Phenasteron, Leptasteron and Subasteron. Memoirs of the Queensland Museum 46: 359-385.

Dyal S. 1935. Fauna of Lahore. 4. Spiders of Lahore. Bulletin of the Department of Zoology of the Panjab University 1: 119-252.

Edgar W.D. 1969. Prey and feeding behaviour of adult females of the wolf spider Pardosa amentata (Clerck). Netherlands Journal of Zoology 20: 487-491. https://doi.org/10.1163/002829670X00259

Gajbe U.A. 2004. Studies on some spiders of the family Lycosidae (Araneae: Arachnida) from Madhya Pradesh, India. Records of the Zoological Survey of India, Occasional Paper 221: 1-40.

Hallander H. 1970. Prey, cannibalism and microhabitat selection in the wolf spiders Pardosa chelata O.F. Müller and P. pullata Clerck. Oikos 21: 337-340. https://doi.org/10.2307/3543691

Jocqué R. \& Alderweireldt M. 2006. Lycosidae: the grassland spiders. Acta Zoologica Bulgarica, Suppl. 1: $125-130$.

Jocqué R., Russell-Smith A. \& Alderweireldt M. 2011. Katableps, a new genus of lycosid spiders from the forests of Madagascar (Araneae: Lycosidae). Bulletin of the British Arachnological Society 15: 181187.

Karsch F. 1879. Arachnologische Beiträge. Zeitschrift für die gesammten Naturwissenschaften 52: 534562.

Karsch F. 1892. Arachniden von Ceylon und von Minikoy gesammelt von den Herren Doctoren P. und F. Sarasin. Berliner Entomologische Zeitschrift 36: 267-310.

Siyam M., Dunlop J.A. \& El-Hennawy H.K. 2015. New spider records from the Republic of the Sudan. Arachnology 16 (7): 264-272. https://doi.org/10.13156/arac.2015.16.7.264

Tikader B.K. \& Malhotra M.S. 1980. Lycosidae (Wolf-spiders). Fauna India (Araneae) 1: 248-447.

Yin C.M. \& Peng X.J. 1997. A new species of the genus Ocyale (Araneae, Lycosidae) from China. Acta Arachnologica Sinica 6: 6-8.

Manuscript received: 8 November 2016

Manuscript accepted: 12 January 2017

Published on: 3 October 2017

Topic editor: Koen Martens

Desk editor: Chloe Chester

Printed versions of all papers are also deposited in the libraries of the institutes that are members of the EJT consortium: Muséum national d'Histoire naturelle, Paris, France; Botanic Garden Meise, Belgium; Royal Museum for Central Africa, Tervuren, Belgium; Natural History Museum, London, United Kingdom; Royal Belgian Institute of Natural Sciences, Brussels, Belgium; Natural History Museum of Denmark, Copenhagen, Denmark; Naturalis Biodiversity Center, Leiden, the Netherlands; Museo Nacional de Ciencias Naturales-CSIC, Madrid, Spain; Real Jardín Botánico de Madrid CSIC, Spain. 